\title{
Flattening the Corticosterone Rhythm Attenuates 5-HTIA Autoreceptor Function in the Rat: Relevance for Depression
}

\author{
Melville M Leitch*,', Colin D Ingram', Allan H Young', Richard McQuade' and Sarah E Gartside' \\ 'Psychobiology Research Group, Stanley Research Centre, The Medical School, University of Newcastle upon Tyne, Newcastle upon Tyne, UK
}

\begin{abstract}
Depression is associated with glucocorticoid abnormalities, in particular a flattening of the diurnal cortisol rhythm. Recent data suggest that an important factor in the aetiology of depression may be a deficit in the function and expression of 5-HTIA receptors, which has been reported in depressed patients. The present study assessed the possibility that this cortisol abnormality is causal in the 5-HTIA receptor deficits. First, a rat model of flattened glucocorticoid rhythm was developed. Controlled release corticosterone pellets implanted for 14 days flattened the corticosterone rhythm and maintained levels constant midway between the nadir and zenith levels observed in sham-operated rats. Secondly, using microdialysis to assess 5-HT release in the hippocampus, the inhibitory response to 8-OHDPAT was measured to determine the sensitivity of somatodendritic 5-HT IA autoreceptors. Corticosterone treatment was found to induce a significant attenuation in the response to 8-OHDPAT, indicating functional desensitization of somatodendritic 5-HT IA autoreceptors. There was no effect of corticosterone treatment on basal extracellular 5-HT levels. The data suggest that the glucocorticoid abnormalities associated with depression may impact on the functioning of 5- $\mathrm{H} \mathrm{T}_{\text {IA }}$ receptors in the brain. These findings suggest that resolution of cortisol abnormalities may be a valuable target for pharmacotherapy in the treatment of depression.

Neuropsychopharmacology (2003) 28, I 19-125. doi: I 0.1038/sj.npp. I 300016
\end{abstract}

Keywords: corticosterone; serotonin; 5- $\mathrm{HT}_{\text {IA }}$ receptor; autoreceptor; microdialysis; raphe nuclei

\section{INTRODUCTION}

The hypothalamic-pituitary-adrenal (HPA) axis is the major regulator of circulating levels of the glucocorticoid hormones - cortisol in man and corticosterone in rodents. It has long been observed that a significant proportion of depressed patients have elevated plasma cortisol levels (Gibbons, 1964), possibly due to abnormalities in negative feedback at multiple levels in the HPA axis (Holsboer et al, 1995). More recently, the early observation of elevated plasma cortisol has been reported in more detail, establishing that in depressed patients cortisol levels at the usual afternoon nadir are elevated approximately two-fold while at the early morning peak levels are only marginally raised. Hence, the diurnal rhythm shows a flattened profile (Deuschle et al, 1997; Wong et al, 2000). Upon recovery from depression, HPA axis function and plasma cortisol levels have been reported to return towards normal (Gibbons, 1964; Holsboer et al, 1995), suggesting that these abnormalities are state dependent.

That hypersecretion of cortisol may be causative in the development of depression is suggested by findings in

*Correspondence: MM Leitch, Psychobiology Research Group, Stanley Research Centre, The Medical School, University of Newcastle upon Tyne, Framlington Place, Newcastle upon Tyne NE2 4HH, UK. Tel: +44 191 222 7583, Fax: +44 191 222 5227, E-mail: m.m.leitch@ncl.ac.uk Received 23 April 2002; revised 17 June 2002; accepted 19 June 2002 patients with Cushing's disease. These patients typically have plasma cortisol levels that are three-fold those of normal healthy subjects, and within this group the prevalence of depression is higher than in the normal population (Cohen, 1980; Kelly et al, 1983). Furthermore, depressive symptoms resolve on treatment of the primary endocrine disorder (Cohen, 1980; Kelly et al, 1983).

It has long been established that depressed patients have a dysfunctional 5-HT system (Asberg and Traskman, 1981; Cowen et al, 1990; Yates et al, 1990). More recently, several strands of evidence have emerged that specifically implicate the $5-\mathrm{HT}_{1 \mathrm{~A}}$ receptor in this condition. The $5-\mathrm{HT}_{1 \mathrm{~A}}$ receptor is expressed both as a postsynaptic receptor in the forebrain and as an autoreceptor on 5-HT neurones in the raphe nuclei (Pazos and Palacios, 1985; Verge et al, 1985, 1986). Depressed patients exhibit an attenuation of $5-\mathrm{HT}_{1 \mathrm{~A}}$ receptor mediated neuroendocrine and hypothermic responses, reflecting dysfunction of postsynaptic $5-\mathrm{HT}_{1 \mathrm{~A}}$ receptors and $5-\mathrm{HT}_{1 \mathrm{~A}}$ autoreceptors, respectively (Lesch, 1991; Cowen et al, 1994; Shapira et al, 2000). Furthermore, a decrease in the $5-\mathrm{HT}_{1 \mathrm{~A}}$ binding potential, as determined by positron emission tomography, has been demonstrated in multiple forebrain areas of depressed patients (Drevets $\mathrm{et} \mathrm{al}$, 1999; Sargent et al, 2000) as well as in the raphe (Drevets et al, 1999, 2000; Sargent et al, 2000).

That the 5-HT dysfunction in depression may be secondary to cortisol abnormalities is suggested by a wealth of evidence from preclinical studies. Thus, $5-\mathrm{HT}_{1 \mathrm{~A}}$ function 
has been reported to be attenuated in rodents following chronic stress or the administration of large doses of corticosterone (Young et al, 1994; Takao et al, 1997). Of particular note are the findings that chronic corticosterone attenuates postsynaptic $5-\mathrm{HT}_{1 \mathrm{~A}}$ receptor function in the hippocampus (Beck et al, 1994; Karten et al, 1999) and hypothalamus (Haleem, 1992). An attenuation of 5- $\mathrm{HT}_{1 \mathrm{~A}}$ autoreceptor function has also been reported following chronic corticosterone (McAllister-Williams et al, 2001; Young et al, 1994).

While the above data provide strong evidence for a modulatory action of glucocorticoids on $5-\mathrm{HT}_{1 \mathrm{~A}}$ receptor function, it should be noted that these studies have examined only the effects of high doses of corticosterone or severe stressors. Whether the moderate abnormalities in glucocorticoids of the type seen in depression also induce such changes remains unclear. The present study sought to examine the question, of whether changes in the corticosterone rhythm can impact upon the function of $5-\mathrm{HT}_{1 \mathrm{~A}}$ receptors. To address this question, we developed a model of flattened corticosterone rhythm in the rat and assessed the effect of this treatment on the function of somatodendritic $5-\mathrm{HT}_{1 \mathrm{~A}}$ autoreceptor using in vivo microdialysis.

\section{MATERIALS AND METHODS}

\section{Animals}

Male Sprague-Dawley rats purchased from Bantin and Kingman (UK) were group-housed with ad libitum access to food and water under controlled environmental conditions (temperature: $20^{\circ} \mathrm{C}$; humidity: $30-50 \%$ ). Animals were allowed to acclimatize for 1 week before undergoing any procedures. For the majority of the studies, animals were kept on a $12 \mathrm{~h}$ light/dark cycle; however for the remote blood sampling, animals were kept on a $14 \mathrm{~h}$ light $/ 10 \mathrm{~h}$ dark cycle. In both cases lights off was at $7 \mathrm{pm}$. This study was carried out in accordance with the Guide for the Care and Use of Laboratory Animals as adopted and promulgated by the National Institutes of Health.

\section{Chronic Corticosterone Treatment}

Commercially made corticosterone pellets (Innovative Research of America, USA) designed to release $75 \mathrm{mg}$ of corticosterone over 21 days ( $3.6 \mathrm{mg} /$ day) were used. Pellets were implanted subcutaneously on the right flank of rats weighing approximately $180 \mathrm{~g}$ under isoflurane anaesthesia. Immediately following surgery, $0.05 \mathrm{mg} / \mathrm{kg}$ of the analgesic buprenorphine was given subcutaneously. Sham rats underwent the same surgical procedure but no pellet was implanted.

\section{$24 \mathrm{~h}$ Corticosterone Profile}

Small groups of corticosterone-treated and sham-operated animals underwent continual remote blood sampling in order to establish the $24 \mathrm{~h}$ whole-blood corticosterone profile using previously described methods (Lightman et al, 2000). Animals were again anaesthetized with isoflurane 8 days after implantation of pellets or sham operation. The jugular vein was cannulated with a silastic-tipped poly- propylene cannula, which was exteriorized at the top of the head and passed out through a protective steel spring to a swivel. Animals were allowed to recover from the anaesthetic and were housed singly in the test cages. After 3 days (day 11), cannulae were connected to the remote sampling device (Lightman et al, 2000). Samples of whole blood (10 $\mu \mathrm{l}$ diluted to $50 \mu \mathrm{l}$ in heparinized saline) were taken at $10 \mathrm{~min}$ intervals over a $24 \mathrm{~h}$ period. The removed blood volume was replaced by infusion of heparinized saline. A total of 12 consecutive samples $(2 \mathrm{~h})$ were pooled before analysis for corticosterone using a commercially available radioimmunoassay kit (ICN Pharmaceuticals Inc., Orangeburg, NY).

\section{Serum Corticosterone}

Groups of corticosterone-treated and sham-operated animals were weighed daily before and from day 5 following surgery. On days 11, 12, and 13 following surgery, the animals were briefly handled by the experimenter. Between 10 and $16 \mathrm{~h}$ before being killed, the animals were moved in their home cages to the experimental room and left to acclimatize. Groups of animals were killed at 8 am and $7 \mathrm{pm}$ by decapitation; trunk blood was collected and left to coagulate on ice. Blood was centrifuged at $3000 \mathrm{~g}$ for $10 \mathrm{~min}$, and serum was removed and stored at $-20^{\circ} \mathrm{C}$ until analysis for corticosterone using a commercially available radioimmunoassay kit (ICN Pharmaceuticals Inc., Orangeburg, $\mathrm{NY}$ ). The left adrenal gland was also removed and weighed.

\section{Microdialysis}

Microdialysis was carried out in a group of naive rats, and in corticosterone-treated and sham-operated groups 14 days after surgery. In all cases, the procedure was started at around 8:30 am and was typically finished before $3 \mathrm{pm}$. Microdialysis was carried out as described elsewhere (Sharp et al, 1989a). Briefly, rats were anaesthetized with chloral hydrate $(500 \mathrm{mg} / \mathrm{kg}$ i.p.) and a concentric microdialysis probe with a $4 \mathrm{~mm}$ dialysis window was stereotaxically implanted into the right ventral hippocampus (stereotaxic coordinates: caudal $5.2 \mathrm{~mm}$, lateral $5.2 \mathrm{~mm}$, ventral $-8.5 \mathrm{~mm}$ from bregma and dura surface, with the incisor bar set $3.3 \mathrm{~mm}$ below the interaural line). The dialysis probe was continuously perfused at $2.3 \mu \mathrm{l} / \mathrm{min}$ with artificial CSF $\left(140 \mathrm{mM} \mathrm{NaCl}, 3 \mathrm{mM} \mathrm{KCl}, 2.4 \mathrm{mM} \mathrm{CaCl}, 1 \mathrm{mM} \mathrm{MgCl}_{2}\right.$, $1.2 \mathrm{mM} \mathrm{Na}_{2} \mathrm{HPO}_{4}, 0.27 \mathrm{mM} \mathrm{NaH} \mathrm{PO}_{4}, 7.2 \mathrm{mM}$ glucose, $\mathrm{pH}$ 7.4) containing $10 \mu \mathrm{M}$ fluoxetine. Dialysates collected over a $20 \mathrm{~min}$ period were injected manually on to a highperformance liquid chromatography (HPLC) system and separation was performed on a $100 \mathrm{~mm} \times 4.6 \mathrm{~mm} 3 \mu \mathrm{m}$ microsorb 100 C18 HPLC column (Varian, USA) maintained at $30^{\circ} \mathrm{C}$ using a column heater (Waters). Mobile phase $\left(127 \mathrm{mM} \mathrm{NaH} \mathrm{PO}_{4}, 25 \mu \mathrm{M}\right.$ octanesulfonic acid, $0.045 \%$ EDTA, $15 \%$ methanol, $\mathrm{pH} 3.9$ ) was pumped through the system at $1.1 \mathrm{ml} / \mathrm{min}$ and $5-\mathrm{HT}$ was detected using a Coulochem II (ESA Inc, USA) electrochemical detector fitted with a 5020 guard cell $(E=250 \mathrm{mV})$ and a $5014 \mathrm{~B}$ microdialysis cell $(E 1=60 \mathrm{mV}$ and $E 2=200 \mathrm{mV})$. The resulting peak height was measured and quantified with reference to an external standard solution containing 5 -HT $(500 \mathrm{fmol} / 50 \mu \mathrm{l})$. The lower limit of detection $(2 \times$ noise $)$ of the HPLC assay for 5-HT was around $4 \mathrm{fmol}$. 
Following establishment of a stable baseline of dialysate 5 -HT, rats were injected with the 5- $\mathrm{HT}_{1 \mathrm{~A}}$ agonist 8-hydroxy2 -(di- $n$-propylamino)tetralin (8-OHDPAT) (30 and $100 \mu \mathrm{g} /$ $\mathrm{kg}$ ) or water vehicle, in a volume of $1 \mathrm{ml} / \mathrm{kg}$ body weight administered via the lateral tail vein. Dialysates were collected for a further $120 \mathrm{~min}$ and assayed for $5-\mathrm{HT}$.

\section{Data Analysis}

Data shown are mean \pm SEM $(n)$. In the figures, dialysate 5-HT data are presented as change from baseline (average of three predrug values). Statistical analysis of absolute 5-HT levels was carried out using a two-way ANOVA with repeated measures. Significance at the $95 \%$ level is reported.

\section{RESULTS}

\section{Characterization of Modified Rhythm of HPA Activity}

As shown in Figure 1, sham-treated animals exhibited a marked rhythm of whole-blood corticosterone levels over the $24 \mathrm{~h}$ sampling period. Corticosterone was lowest in the sample taken during the $2 \mathrm{~h}$ period immediately before lights on, and highest in the sample taken $14 \mathrm{~h}$ later at 5$6 \mathrm{pm}$. In animals implanted with a $75 \mathrm{mg}$ corticosterone pellet, no rhythm was observed, and blood corticosterone levels were static at a level midway between the zenith and the nadir of the sham-operated animals. Moreover, the $24 \mathrm{~h}$ area under the curve (AUC) for blood corticosterone did not differ between animals implanted with a $75 \mathrm{mg}$ corticosterone pellet $\left(24.8 \pm 6.8 \quad\right.$ (3) $\mathrm{ng} \mathrm{ml}^{-1}$ day) and sham-operated animals $\left(26.7 \pm 4.9 \quad\right.$ (4) $\mathrm{ng} \mathrm{ml}^{-1}$ day, $p>0.05)$.

Figure 2a shows the body weight gain of sham-operated and corticosterone-treated rats over the postoperative period. Rats weighed $175 \pm 1 \mathrm{~g}$ (32) at the time of surgery. Rats that underwent sham surgery increased their body weight by approximately $6.5 \mathrm{~g} /$ day so that their final body weight after 14 days was $274 \pm 4 \mathrm{~g}$ (16). Rats implanted with

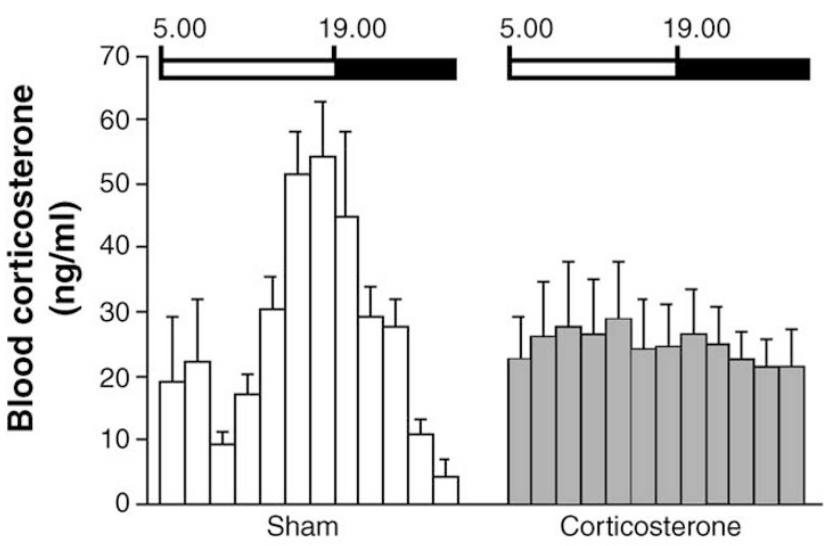

Treatment

Figure I Diurnal profile of circulating corticosterone in corticosteronetreated and sham-operated rats. Whole blood was sampled at $10 \mathrm{~min}$ intervals on day | | following the implantation of a corticosterone pellet or sham operation. Open and shaded bars represent the light and dark phases, respectively. Lights off was at $7 \mathrm{pm}$. Data are mean \pm SEM of groups of three and four rats.
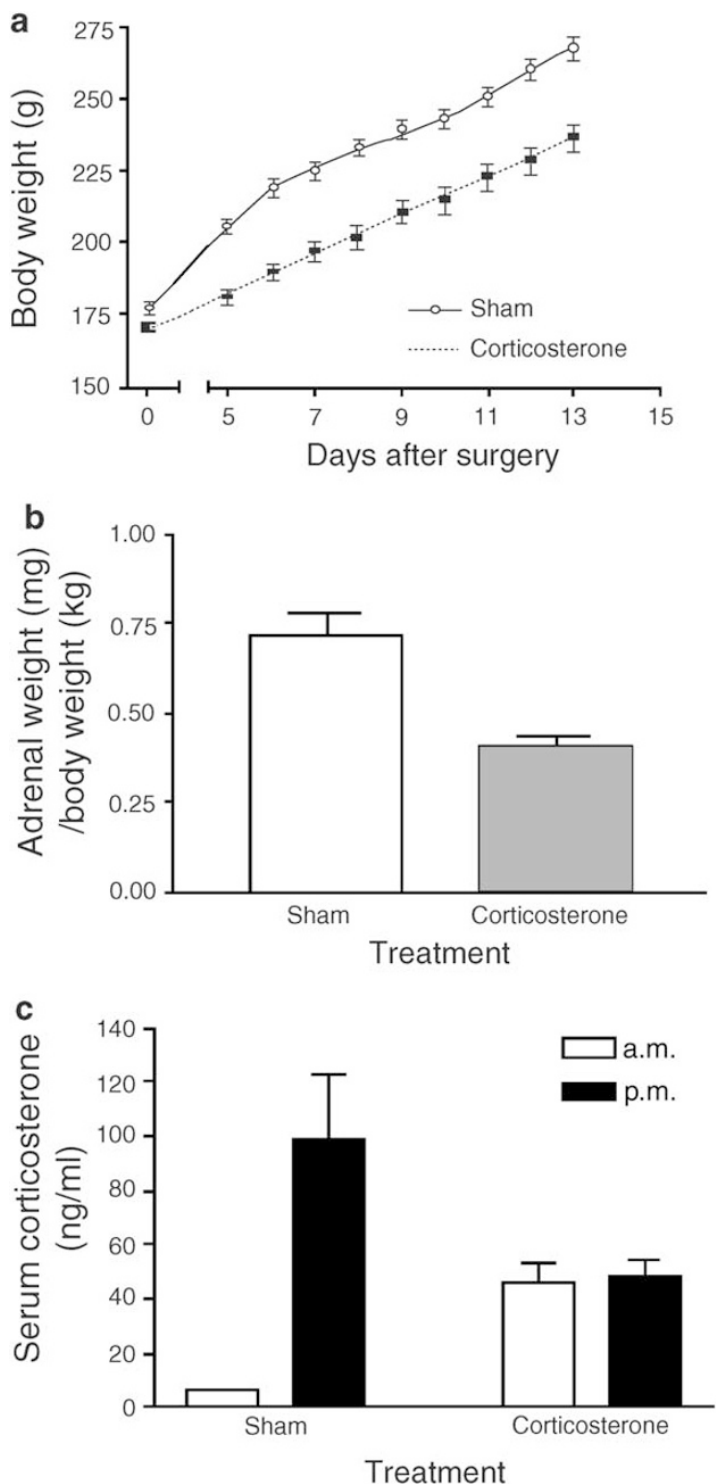

Figure 2 Body weights (a), adrenal:body weight ratio (b), and serum corticosterone levels (c) in corticosterone-treated and sham-operated rats. Groups of 16 animals were treated for 14-15 days. Animals were weighed before treatment and daily from day 5 . Adrenal glands were removed at sacrifice and weighed. Serum corticosterone levels were measured in trunk blood collected at $7 \mathrm{pm}$ on day $14(n=8)$ or 8 am on day $15(n=8)$. Data shown are mean \pm SEM.

a $75 \mathrm{mg}$ corticosterone pellet had a reduced weight gain in the first 5 days following surgery, after which they regained weight at a similar rate to sham rats (final body weight $=237 \pm 4 \mathrm{~g}(16))$. That the rate of weight gain was similar in the two groups was confirmed by two-way ANOVA (weight gain from day 5), which showed significant main effects of treatment $\left(\mathrm{F}_{1,270}=335.1, p<0.0001\right)$ and day $\left(\mathrm{F}_{8,270}=104.6, p<0.0001\right)$ but no significant interaction.

Corticosterone treatment caused a marked decrease in adrenal weight measured at day 14 following surgery. When adrenal weight was corrected for body weight (ie adrenal weight in milligrams divided by body weight in kilograms), the value in corticosterone-treated animals was approximately half that in sham animals (Figure $2 b$ ). 
Figure 2c shows serum corticosterone levels in corticosterone-treated and sham-operated animals taken at $7 \mathrm{pm}$ on day 14 and $8 \mathrm{am}$ on day 15 . While in sham-operated animals, there was a large difference between serum corticosterone at $7 \mathrm{pm}$ and $8 \mathrm{am}$, in corticosterone-treated animals there was no such diurnal difference and corticosterone levels were midway between the am and pm levels of the sham-operated animals.

\section{Effect of 8-OHDPAT on Hippocampal Dialysate 5-HT: Dose-Response}

In naive animals, systemic administration of 8-OHDPAT $(0-100 \mu \mathrm{g} / \mathrm{kg})$ caused a dose-dependent decrease in 5-HT in dialysates of the ventral hippocampus (Figure 3 ). For both 8-OHDPAT doses, the maximum effect was evident in the sample collected $40 \mathrm{~min}$ postdrug (Figure 3 ). In animals treated with $100 \mu \mathrm{g} / \mathrm{kg}$ 8-OHDPAT, dialysate 5-HT was reduced by a maximum of $21 \pm 6.1 \mathrm{fmol}$ and this decrease was maintained for a further hour. In animals treated with $30 \mu \mathrm{g} / \mathrm{kg}$ 8-OHDPAT, the maximum effect was less $(14 \pm 1.8 \mathrm{fmol})$ and the duration of the response was shorter. In the group treated with vehicle, 5-HT levels were maintained around the basal level over the experimental period. Basal levels of 5-HT in the three groups combined were $49.5 \pm 6.5 \mathrm{fmol}(14)$.

\section{Effect of Corticosterone Treatment on 5- $\mathrm{HT}_{1 \mathrm{~A}}$ Function}

Chronic treatment with corticosterone had no effect on basal levels of 5-HT in the ventral hippocampus in the presence of fluoxetine. Basal values were $39.3 \pm 5.1 \mathrm{fmol} /$ sample (7) in sham-treated animals and $44.4 \pm 10.1 \mathrm{fmol} /$ sample (6) in rats treated with corticosterone.

In rats treated with corticosterone, the 5-HT response to a submaximal dose of 8 -OHDPAT $(30 \mu \mathrm{g} / \mathrm{kg})$ was markedly attenuated (Figure 4). This effect of corticosterone treatment was apparent in the 40 and $60 \mathrm{~min}$ samples and represented an approximate halving of the magnitude of the response to 8-OHDPAT. A two-way ANOVA of the raw data

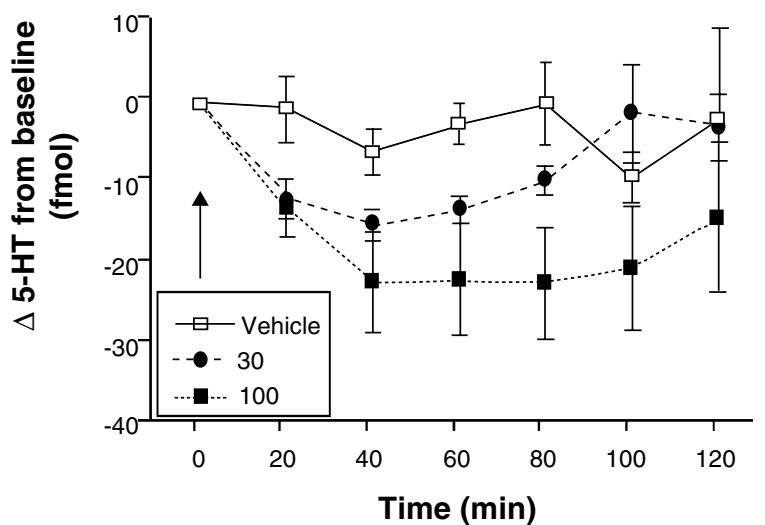

Figure 3 Effect of 8-OHDPAT or vehicle on 5-HT in dialysates of the ventral hippocampus. Naive animals ( $n=5$ per group) were injected i.v. with vehicle, or 30 or $100 \mu \mathrm{g} / \mathrm{kg} 8$-OHDPAT as indicated by the arrow. Data are presented as change from baseline (average of three predrug values). Data are mean \pm SEM.

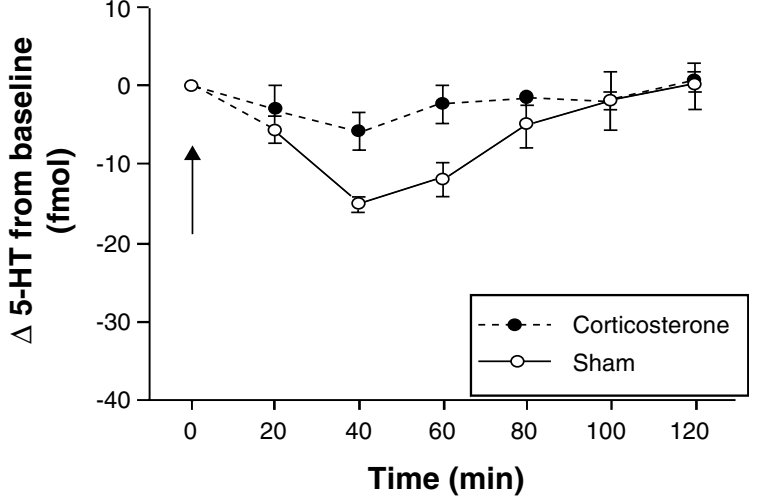

Figure 4 Effect of corticosterone treatment on the 8-OHDPAT-induced decrease in dialysate $5-\mathrm{HT}$. Corticosterone-treated $(n=6)$ and shamoperated $(n=7)$ rats were injected with $30 \mu \mathrm{g} / \mathrm{kg} 8$-OHDPAT i.v. on day 14 following surgery. 5-HT was measured in dialysates of the ventral hippocampus. Data are presented as change from baseline (mean of three predrug values). Data shown are mean \pm SEM.

revealed a significant main effect of time $\left(\mathrm{F}_{8,88}=8.5\right.$; $p<0.0001)$ and a significant treatment by time interaction $\left(\mathrm{F}_{8,88}=2.5 ; p<0.05\right)$. There was no significant main effect of treatment.

\section{DISCUSSION}

This study sought to examine the question of whether the type of glucocorticoid abnormality commonly observed in depressed patients alters the function of somatodendritic 5$\mathrm{HT}_{1 \mathrm{~A}}$ autoreceptors. Laboratory rats were implanted with controlled release corticosterone pellets to develop a model of raised nadir corticosterone level and a flattened corticosterone rhythm. Flattening the corticosterone rhythm resulted in a significant attenuation of $5-\mathrm{HT}_{1 \mathrm{~A}}$ autoreceptor function assessed using in vivo microdialysis.

Rats were treated with controlled release corticosterone pellets releasing $3.6 \mathrm{mg} /$ day for 14 days. We aimed to mimic the situation in depression, a chronic disorder frequently lasting for months. Furthermore, it is established that glucocorticoids have genomic effects via their intracellular receptors, and these effects might be expected to be slow in onset (Reul et al, 1987). The average daily dose of corticosterone was around $18 \mathrm{mg} / \mathrm{kg} /$ day, although the dose did vary over the 2 weeks because of increase in the body weight of the rats. Under these conditions, rats had a flattened diurnal blood corticosterone rhythm when measured using a continuous sampling procedure, with circulating corticosterone levels being remarkably constant over the day. These data confirm and extend those of Akana et al (1992), Young et al (1995) and Young (1996), who used cholesterol/corticosterone pellets to provide continuous slow release of corticosterone and found that such a method of administration decreased peak and increased nadir corticosterone levels. The present data also showed that the AUC for $24 \mathrm{~h}$ blood corticosterone was unchanged in corticosterone-treated rats compared to control rats. Taken together, the above data suggest that implanting corticosterone pellets flattens the diurnal corticosterone rhythm without raising the total daily amount of circulating 
corticosterone. The paradigm used here differs from that used in previous studies examining the effect of corticosterone on 5- $\mathrm{HT}_{1 \mathrm{~A}}$ receptor function (Gur et al, 2001; McAllister-Williams et al, 2001; Young et al, 1994) both in terms of the daily dose being lower (18 compared to $50 \mathrm{mg} /$ $\mathrm{kg}$ ) and in terms of the profile produced (flattened rhythm vs high peak and low trough resulting from daily injections). A further important feature of the current model is that the animals were adrenally intact, thereby obviating the possible confounding effects of removal of aldosterone and adrenaline.

Corticosterone levels in serum samples taken at $8 \mathrm{am}$ and $7 \mathrm{pm}$ (times of the nadir and zenith, unpublished findings) were in accord with the findings from the $24 \mathrm{~h}$ sampling, showing no diurnal change in corticosterone-treated animals. Although the levels of corticosterone measured in serum at the zenith were higher than those measured in whole blood, this difference may be accounted for by the partition of corticosterone into the plasma fraction due to binding to globulins. The higher nadir corticosterone levels in control rats undergoing continuous sampling may be explained by the fact that these rats had undergone an additional surgical procedure 3 days before sampling and were individually housed (a known mild stressor (Fagin et al, 1983)) at the time of sampling.

That administration of exogenous corticosterone led to a flattening of the rhythm rather than an absolute increase in circulating corticosterone levels is evidence of the influence of the negative feedback control of corticosterone. Administration of exogenous corticosterone has been previously reported to decrease adrenal weight in a dose-dependent manner (Akana et al, 1992), probably via a decrease in $\mathrm{ACTH}$ - the major determinant of adrenal weight via its trophic effects. In accord with these data, we found that the adrenal glands in rats treated for 14 days with corticosterone showed a high degree of atrophy compared to controls. It is of note that the corticosterone treatment regime did not appear to adversely affect the general health and well-being of the animals. Thus, although corticosterone-treated animals were lighter at the end of the treatment period, this was accounted for by low weight gain immediately after pellet implantation, and their weight gain was normal for the latter part of the treatment period.

In summary, the regime of corticosterone treatment used here produced a flattening of the corticosterone rhythm. In depressed patients, plasma cortisol levels are typically raised at both the nadir and the zenith, (Deuschle et al, 1997; Wong et al, 2000). However, the proportional increase at the nadir is greater than at the zenith, with the result that the diurnal rhythm becomes somewhat flattened. Although in our rat model, corticosterone levels at the zenith, of the rhythm were reduced rather than elevated, the features of raised nadir and flattened rhythm seen in depressed patients were effectively reproduced. It is perhaps of note that the profile we obtained is in fact very similar to that observed in the elderly (Ferrari et al, 2000).

In rats with flattened corticosterone rhythm and controls, microdialysis was used to measure basal extracellular 5-HT and $5-\mathrm{HT}_{1 \mathrm{~A}}$ autoreceptor sensitivity. In this study, we measured dialysate 5-HT in the ventral hippocampus, an area that is innervated by neurones projecting from both the dorsal raphe nucleus (DRN) and the median raphe nucleus (MRN) (McQuade and Sharp, 1997). The selective 5-HT reuptake inhibitor fluoxetine was included in the artificial CSF. Since changes in dialysate 5-HT reflect an aggregate of changes in release and reuptake, blockade of reuptake by fluoxetine allows any changes in dialysate 5-HT to be interpreted as changes in 5-HT release. In addition, this paradigm has the practical implication of preventing 5HT levels falling below the sensitivity of the assay and hence allowing more accurate determination of the magnitude of inhibitory responses.

Using this methodology, the inhibition of 5-HT release in response to a submaximal dose $(30 \mu \mathrm{g} / \mathrm{kg})$ of 8 -OHDPAT was found to be significantly attenuated in corticosteronetreated rats. 8 -OHDPAT is a selective $5-\mathrm{HT}_{1 \mathrm{~A}}$ receptor agonist and its systemic administration has been shown to inhibit both 5-HT neuronal firing and 5-HT release (Hajós et al, 1995; Sharp et al, 1989b). This 5- $\mathrm{HT}_{1 \mathrm{~A}}$ receptor agonist-induced inhibition of 5-HT neuronal activity is thought to be consequent upon stimulation of $5-\mathrm{HT}_{1 \mathrm{~A}}$ autoreceptors located on 5-HT neurons in the DRN and MRN (Sharp and Hjorth, 1990). Hence, this finding of an attenuated response in the corticosterone-treated animals is suggestive of a functional desensitization of these somatodendritic autoreceptors. A caveat to this conclusion is that DRN firing has also been shown to be under the inhibitory influence of $5-\mathrm{HT}_{1 \mathrm{~A}}$ receptors located in the prefrontal cortex (Ceci et al, 1994; Hajós et al, 1999). Since the agonist drug was administered systemically, it is possible that the change observed reflects an alteration in the sensitivity of postsynaptic $5-\mathrm{HT}_{1 \mathrm{~A}}$ receptors in addition to that of $5-\mathrm{HT}_{1 \mathrm{~A}}$ autoreceptors.

Interestingly, basal levels of 5-HT did not differ between corticosterone-treated rats and controls, indicating that the corticosterone treatment does not affect the basal release of 5-HT from terminals in the hippocampus. Although activation of the $5-\mathrm{HT}_{1 \mathrm{~A}}$ receptor inhibits $5-\mathrm{HT}$ release, evidence suggests that there is no appreciable $5-\mathrm{HT}_{1 \mathrm{~A}^{-}}$ receptor-mediated inhibitory tone on 5-HT firing or release under physiological conditions (Baraban and Aghajanian, 1980; Hjorth et al, 1995). Basal 5-HT firing and terminal 5HT release in vivo are primarily controlled by $\alpha_{1}$ adrenergicreceptor-mediated excitation (Gartside et al, 1995; Johnson et al, 2002). Hence, our finding of decreased $5-\mathrm{HT}_{1 \mathrm{~A}}$ receptor sensitivity would not be expected to result in an increase in basal release of 5-HT.

One further point of discussion is that, in the present study, we measured $5-\mathrm{HT}_{1 \mathrm{~A}}$ receptor sensitivity in the anaesthetized rat. It is established that many anaesthetics increase corticosterone acutely; however, data from our own laboratory indicate that corticosterone has no acute effect on $5-\mathrm{HT}_{1 \mathrm{~A}}$ receptor sensitivity (Fairchild and Ingram, 2001). These data suggest that differences between the groups were accounted for by the chronic treatment rather than by differences in their corticosterone response to acute anaesthesia.

The present data indicate that a very moderate dose of corticosterone attenuates $5-\mathrm{HT}_{1 \mathrm{~A}}$ autoreceptor function. The particular corticosterone profile obtained would suggest that this effect is due to flattening of the rhythm rather than elevation of corticosterone since there was no overall increase in daily corticosterone exposure and blood levels at no time exceeded the normal diurnal zenith. 
Interestingly, the effect on $5-\mathrm{HT}_{1 \mathrm{~A}}$ autoreceptor function of this corticosterone manipulation is very similar to that observed with high doses of corticosterone (McAllisterWilliams et al, 2001; Young et al, 1994) or chronic stress (Laaris et al, 1999; Lanfumey et al, 1999). Our data are at odds, however, with a recent microdialysis study that failed to demonstrate any effect of chronic corticosterone treatment on the response to 8-OHDPAT (Gur et al, 2001). These contrasting outcomes may be explained by differences in the methodology between the two studies including the dose of 8 -OHDPAT $(200 \mu \mathrm{g} / \mathrm{kg})$ used by Gur et al (2001), which may have been supramaximal with respect to the inhibition of 5-HT release.

Although the mechanism underlying the change in 5$\mathrm{HT}_{1 \mathrm{~A}}$ receptor sensitivity was not the focus of the present study, there is evidence to suggest that the observed effects of flattening the corticosterone rhythm are likely to be mediated by glucocorticoid receptors (GRs). Although the genomic effects of corticosterone are mediated by GRs and mineralocorticoid receptors (MRs), only GRs are present in the cell bodies of 5-HT neurons in the DRN (Harfstrand et al, 1986). Furthermore, our corticosterone manipulation might be expected to have a major impact on GR activation since evidence suggests that GR activation (but not MR activation) varies widely over the normal diurnal variation in corticosterone levels (Reul and de Kloet, 1985).

The sensitivity and binding potential of $5-\mathrm{HT}_{1 \mathrm{~A}}$ receptors, including those located in the DRN, were shown to be attenuated in depressed patients (Cowen et al, 1994; Drevets et al, 1999; Lesch 1991; Sargent et al, 2000; Shapira et al, 2000). The present data suggest that these $5-\mathrm{HT}_{1 \mathrm{~A}}$ receptor deficits may be secondary to the cortisol abnormalities frequently seen during episodes of depression (Deuschle et al, 1997; Wong et al, 2000). If this somatodendritic 5- $\mathrm{HT}_{1 \mathrm{~A}}$ receptor desensitization has a causative role in depression, then normalization of cortisol abnormalities in depressed patients may be a valuable treatment target. However, it is of interest that antidepressants also desensitize somatodendritic $5-\mathrm{HT}_{1 \mathrm{~A}}$ receptors when given chronically, an effect that has been suggested to be crucial for their therapeutic effects (Artigas et al, 1996; Blier and Abbott, 2001). Hence in depression, by desensitizing somatodendritic $5-\mathrm{HT}_{1 \mathrm{~A}}$ receptors, alterations in glucocorticoids might act as a 'natural antidepressant'. This raises the possibility that treatment to further flatten (or elevate) cortisol may be an effective antidepressant therapy.

\section{ACKNOWLEDGEMENTS}

This study was supported by the Stanley Medical Research Institute. We would also like to thank Susan Wood, Rob Stewart, and Hannah Orr for their assistance.

\section{REFERENCES}

Akana SF, Scribner KA, Bradbury MJ, Strack AM, Walker CD, Dallman MF (1992). Feedback sensitivity of the rat hypothalamo-pituitary-adrenal axis and its capacity to adjust to exogenous corticosterone. Endocrinology 131: 585-594.

Artigas F, Romero L, de Montigny C, Blier P (1996). Acceleration of the effect of selected antidepressant drugs in major depression by $5-\mathrm{HT}_{1 \mathrm{~A}}$ antagonists. Trends Neurosci 19: 378-383.
Asberg M, Traskman L (1981). Studies of CSF 5-HIAA in depression and suicidal behaviour. Adv Exp Med Biol 133: 739-752.

Baraban JM, Aghajanian GK (1980). Suppression of firing activity of 5-HT neurons in the dorsal raphe by alpha-adrenoceptor antagonists. Neuropharmacology 19: 355-363.

Beck SG, List TJ, Choi KC (1994). Long- and short-term administration of corticosterone alters CA1 hippocampal neuronal properties. Neuroendocrinology 60: 261-272.

Blier P, Abbott FV (2001). Putative mechanisms of action of antidepressant drugs in affective and anxiety disorders and pain. J Psychiatry Neurosci 26: 37-43.

Ceci A, Baschirotto A, Borsini F (1994). The inhibitory effect of 8$\mathrm{OH}-\mathrm{DPAT}$ on the firing activity of dorsal raphe serotoninergic neurons in rats is attenuated by lesion of the frontal cortex. Neuropharmacology 33: 709-713.

Cohen SI (1980). Cushing's syndrome: a psychiatric study of 29 patients. Br J Psychiatry 136: 120-124.

Cowen PJ, Anderson IM, Gartside SE (1990). Endocrinological responses to 5-HT. Ann NY Acad Sci 600: 250-257.

Cowen PJ, Power AC, Ware CJ, Anderson IM (1994). $5-\mathrm{HT}_{1 \mathrm{~A}}$ receptor sensitivity in major depression. A A neuroendocrine study with buspirone. $\mathrm{Br} J$ Psychiatry 164: 372-379.

Deuschle M, Schweiger U, Weber B, Gotthardt U, Korner A, Schmider J et al (1997). Diurnal activity and pulsatility of the hypothalamus-pituitary-adrenal system in male depressed patients and healthy controls. J Clin Endocrinol Metab 82: 234-238.

Drevets WC, Frank E, Price JC, Kupfer DJ, Holt D, Greer PJ et al (1999). PET imaging of serotonin 1A receptor binding in depression. Biol Psychiatry 46: 1375-1387.

Drevets WC, Frank E, Price JC, Kupfer DJ, Greer PJ, Mathis C (2000). Serotonin type-1A receptor imaging in depression. $\mathrm{Nucl}$ Med Biol 27: 499-507.

Fagin KD, Shinsako J, Dallman MF (1983). Effects of housing and chronic cannulation on plasma ACTH and corticosterone in the rat. Am J Physiol 245: E515-E520.

Fairchild G, Ingram CD (2001). Acute and chronic effects of glucocorticoid receptor activation on $5-\mathrm{HT}_{1 \mathrm{~A}}$ receptor mediated autoinhibition in the rat dorsal raphe nucleus (DRN). J Psychopharmacol 15: A28.

Ferrari E, Arcaini A, Gornati R, Pelanconi L, Cravello L, Fioravanti $M$ et al (2000). Pineal and pituitary-adrenocortical function in physiological aging and in senile dementia. Exp Gerontol 35: $1239-1250$.

Gartside SE, Umbers V, Haj M, Sharp T (1995). Interaction between a selective $5-\mathrm{HT}_{1 \mathrm{~A}}$ receptor antagonist and an SSRI in vivo : effects on 5-HT cell firing and extracellular 5-HT. $\mathrm{Br} J$ Pharmacol 115: 1064-1070.

Gibbons JL (1964). Cortisol secretion rate in depressive illness. Arch Gen Psychiatry 10: 572-575.

Gur E, Dremencov E, Lerer B, Newman ME (2001). Functional effects of corticosterone on $5-\mathrm{HT}\left({ }_{1 \mathrm{~A}}\right)$ and $5-\mathrm{HT}\left({ }_{1 \mathrm{~B}}\right)$ receptor activity in rat brain: in vivo microdialysis studies. Eur $J$ Pharmacol 411: 115-122.

Haj M, Gartside SE, Sharp T (1995). Inhibition of median and dorsal raphe neurones following administration of the selective serotonin reuptake inhibitor paroxetine. Naunyn Schmiedebergs Arch Pharmacol 351: 624-629.

Haj M, Haj E, Sharp T (1999). Role of the medial prefrontal cortex in $5-\mathrm{HT}_{1 \mathrm{~A}}$ receptor-induced inhibition of 5-HT neuronal activity in the rat. $\mathrm{Br}$ J Pharmacol 126: 1741-1750.

Haleem DJ (1992). Repeated corticosterone treatment attenuates behavioural and neuroendocrine responses to 8-hydroxy-2-(din-propylamino) tetralin in rats. Life Sci 51: L225-L230.

Harfstrand A, Fuxe K, Cintra A, Agnati LF, Zini I, Wikstr AC et al (1986). Glucocorticoid receptor immunoreactivity in monoami- 
nergic neurons of rat brain. Proc Natl Acad Sci USA 83: 97799783.

Hjorth S, Bengtsson HJ, Milano S, Lundberg JF, Sharp T (1995). Studies on the role of $5-\mathrm{HT}_{1 \mathrm{~A}}$ autoreceptors and alpha 1adrenoceptors in the inhibition of 5-HT release-I. BMY7378 and prazosin. Neuropharmacology 34: 615-620.

Holsboer F, Lauer CJ, Schreiber W, Krieg JC (1995). Altered hypothalamic-pituitary-adrenocortical regulation in healthy subjects at high familial risk for affective disorders. Neuroendocrinology 62: 340-347.

Johnson DA, Gartside SE, Ingram CD (2002). 5- $\mathrm{HT}_{1 \mathrm{~A}}$ receptor mediated autoinhibition does not function at physiological firing rates: evidence from in vitro electrophysiological studies in the rat dorsal raphe nucleus. Neuropharmacology 43: 959-965.

Karten YJ, Nair SM, van Essen L, Sibug R, Jo M (1999). Long-term exposure to high corticosterone levels attenuates serotonin responses in rat hippocampal CA1 neurons. Proc Natl Acad Sci USA 96: 13456-13461.

Kelly WF, Checkley SA, Bender DA, Mashiter K (1983). Cushing's syndrome and depression-a prospective study of 26 patients. Br J Psychiatry 142: 16-19.

Laaris N, Le Poul E, Laporte AM, Hamon M, Lanfumey L (1999). Differential effects of stress on presynaptic and postsynaptic 5hydroxytryptamine-1A receptors in the rat brain: an in vitro electrophysiological study. Neuroscience 91: 947-958.

Lanfumey L, Pardon MC, Laaris N, Joubert C, Hanoun N, Hamon $\mathrm{M}$ et al (1999). 5- $\mathrm{HT}_{1 \mathrm{~A}}$ autoreceptor desensitization by chronic ultramild stress in mice. Neuroreport 10: 3369-3374.

Lesch KP (1991). 5- HT $_{1 \mathrm{~A}}$ receptor responsivity in anxiety disorders and depression. Prog Neuropsychopharmacol Biol Psychiatry 15: 723-733.

Lightman SL, Windle RJ, Julian MD, Harbuz MS, Shanks N, Wood SA et al (2000). Significance of pulsatility in the HPA axis. Novartis Found Symp 227: 244-257.

McAllister-Williams RH, Anderson AJ, Young AH (2001). Corticosterone selectively attenuates 8-OH-DPAT-mediated hypothermia in mice. Int J Neuropsychopharmacol 4: 1-8.

McQuade R, Sharp T (1997). Functional mapping of dorsal and median raphe 5-hydroxytryptamine pathways in forebrain of the rat using microdialysis. J Neurochem 69: 791-796.

Pazos A, Palacios JM (1985). Quantitative autoradiographic mapping of serotonin receptors in the rat brain. I. Serotonin-1 receptors. Brain Res 346: 205-230.

Reul JMHM, de Kloet ER (1985). Two receptor systems for corticosterone in rat brain: microdistribution and differential occupation. Endocrinology 117: 2505-2511.

Reul JMHM, van den Bosch FR, de Kloet ER (1987). Relative occupation of type-I and type-II corticosteroid receptors in rat brain following stress and dexamethasone treatment: functional implications. J Endocrinol 115: 459-467.
Sargent PA, Kjaer KH, Bench CJ, Rabiner EA, Messa C, Meyer J et al (2000). Brain serotonin $1 \mathrm{~A}$ receptor binding measured by positron emission tomography with [11C]WAY-100635: effects of depression and antidepressant treatment. Arch Gen Psychiatry 57: $174-180$

Shapira B, Newman ME, Gelfin Y, Lerer B (2000). Blunted temperature and cortisol responses to ipsapirone in major depression: lack of enhancement by electroconvulsive therapy. Psychoneuroendocrinology 25: 421-438.

Sharp T, Bramwell SR, Grahame-Smith DG (1989a). 5-HT1 agonists reduce 5-hydroxytryptamine release in rat hippocampus in vivo as determined by brain microdialysis. $\mathrm{Br} \mathrm{J}$ Pharmacol 96: 283-290.

Sharp T, Bramwell SR, Hjorth S, Grahame-Smith DG (1989b). Pharmacological characterization of 8-OH-DPAT-induced inhibition of rat hippocampal 5-HT release in vivo as measured by microdialysis. Br J Pharmacol 98: 989-997.

Sharp T, Hjorth S (1990). Application of brain microdialysis to study the pharmacology of the $5-\mathrm{HT}_{1 \mathrm{~A}}$ autoreceptor. J Neurosci Methods 34: 83-90.

Takao K, Nagatani T, Kitamura Y, Yamawaki S (1997). Effects of corticosterone on $5-\mathrm{HT}_{1 \mathrm{~A}}$ and $5-\mathrm{HT}_{2}$ receptor binding and on the receptor-mediated behavioral responses of rats. Eur $J$ Pharmacol 333: 123-128.

Verge D, Daval G, Patey A, Gozlan H, el Mestikawy S, Hamon M (1985). Presynaptic 5-HT autoreceptors on serotonergic cell bodies and/or dendrites but not terminals are of the $5-\mathrm{HT}_{1 \mathrm{~A}}$ subtype. Eur J Pharmacol 113: 463-464.

Verge D, Daval G, Marcinkiewicz M, Patey A, el Mestikawy S, Gozlan $\mathrm{H}$ et al (1986). Quantitative autoradiography of multiple $5-\mathrm{HT}_{1}$ receptor subtypes in the brain of control or 5,7-dihydroxytryptamine-treated rats. J Neurosci 6: 34743482.

Wong ML, Kling MA, Munson PJ, Listwak S, Licinio J, Prolo P et al (2000). Pronounced and sustained central hypernoradrenergic function in major depression with melancholic features: relation to hypercortisolism and corticotropin-releasing hormone. Proc Natl Acad Sci USA 97: 325-330.

Yates M, Leake A, Candy JM, Fairbairn AF, McKeith IG, Ferrier IN (1990). $5 \mathrm{HT}_{2}$ receptor changes in major depression. Biol Psychiatry 27: 489-496.

Young EA (1996). Sex differences in response to exogenous corticosterone: a rat model of hypercortisolemia. Mol Psychiatry 1: 313-319.

Young AH, Goodwin GM, Dick H, Fink G (1994). Effects of glucocorticoids on $5-\mathrm{HT}_{1 \mathrm{~A}}$ presynaptic function in the mouse. Psychopharmacology (Berl) 114: 360-364.

Young EA, Kwak SP, Kottak J (1995). Negative feedback regulation following administration of chronic exogenous corticosterone. $J$ Neuroendocrinol 7: 37-45. 